\title{
Modeling and Analysis Variable Cross Section Pile Driven in Sandy Soil using Finite Element
}

\author{
Russul O. Makki1, a and Mohammed K. Fakhraldin ${ }^{1, \mathrm{~b}}$ * \\ ${ }^{1}$ Civil Engineering Department, University of Kufa Najaf, Iraq.

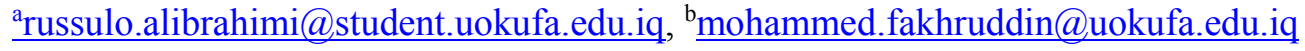

\begin{abstract}
This study focuses on the finite element simulation of piles with different models in sandy soils using the software PLAXIS 3D V20. The parametric study has conducted to investigate the influence of multiple parameters on the axial capacity of steel piles in sandy soil, including the crosssection variables in two cases: open and close-ended piles. The typical circular and square crosssection open and close-ended piles were selected as the reference for comparison with variables crosssection piles. The open-ended tapered pile $3 \mathrm{~b}$ showed an increase in the maximum load capacity about $210 \%$ more than the open-ended circular section, while the close-ended tapered pile $3 \mathrm{~b}$ showed an increase of about $176 \%$ in the axial load capacity more than the solid close-ended circular section. In terms of the effect of pile's type, all of the close-ended sections outperformed the open-ended sections, with the circular section showing a $146 \%$ increase in its close-ended section, while the tapered $3 \mathrm{~b}$ section showed the lowest difference between the close-ended and the open-ended sections with just $120 \%$ increase. These results showed that the tapering pile is much more efficient than any straight-sided pile or even circular pile. The results also showed that a short open-ended pile's capacity is smaller than the corresponding closed-ended pile.
\end{abstract}

Keywords: Tapered pile; square pile; circular pile; open and close-ended piles; finite element method.

\section{Introduction}

The pile foundations are the part of a system used to transmit structural load into the soil at a certain depth below the ground bottom surface level. The key components of the pile foundation are the pile cap and piles. Piles are long and slender members that transfer the load to deeper soil or high bearing capacity rock, avoiding shallow soil with a low bearing capacity [1]. The primary functions of a piled foundation are (a) transferring the load of the structure to a layer of high bearing capacity; (b) increasing the soil bearing capacity; (c) avoiding lateral loads and act as a fender for absorbing wear and shock, (d) preventing differential settlement; (e), transferring loads from a structure to stable bearing strata by readily eroded soils in a scour region, and (e) anchor structures subjected to hydrostatic raised or overturning [2]. A rise in interest in tapered piles has been seen in the last 3 decades. For sand-driven piles and the effect of piles' volume and shape on the pile's capacity was studied by Robinsky et al.[3]. They studied various embedment depth to diameter ratios, instrumented tapered and cylindrical model piles were driven into the sand. These experiments showed that as the piles were progressed, the unit load transfer rate through the pile walls shifted continuously.

Tapered piles were also found to be marginally more powerful than piles with straight sides. The effects of pile taper on cohesionless soil compaction and displacement adjacent to friction tapered piles were also studied [3]. It was found that the tapered pile with most of the load carried by skin friction would support substantially larger loads in comparatively homogeneous cohesionless soils than a straight-sided wall pile with a larger point. The response of straight corrugated piles, wall piles, and tapered piles in permafrost soils has been studied by Ladanyi et al. [4]. Compared to the brittle failure of other types of piles, they proved that the tapered piles were the strongest because they displayed characteristics of strain hardening. A model was also developed for the analysis of tapered piles in which two components modeled the soil resistance: adhesion and friction along the shaft (shearing resistance) being the first component, and the second component was mobilized by the expansion of the hole resulting from the pile entering the soil due to the lateral soil reaction. In an 
experimental field study, the bearing capacity of bored-cast-in-place tapered piles was investigated by [5]. He indicated that the tapered piles tested had a general bearing capacity exceeding 20-30 percent of the specific bearing capacity of straight cylindrical piles of the same length. Local studies have been conducted to investigate the effect of loading type and soil relative density on steel piles' performance $[6,7]$. The tapered pile is shown in Figure 1.

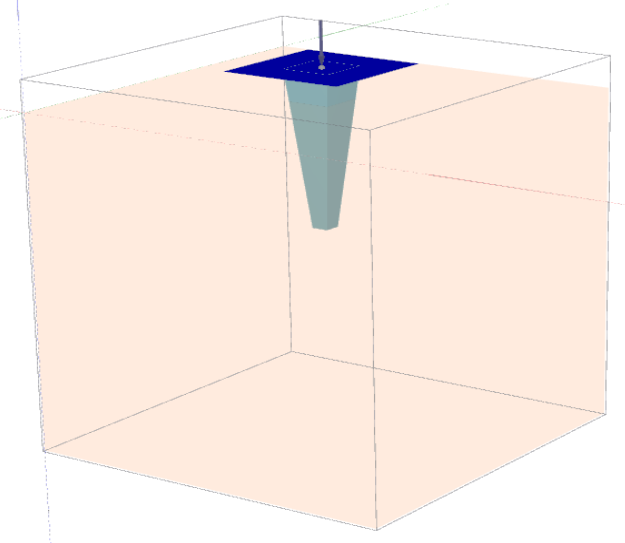

Figure 1. Tapered pile.

The main objective of this work is to investigate the effect of different pile cross-sections on axial load capacity by means of:

1. Using the geotechnical package PLAXIS 3D for modeling conventional straight-sided and tapered piles' sections.

2. Using the hardening soil model with small strain to accurately simulate soil behavior

3. Investigating the effect of section geometry on solid and pipe piles' behavior in terms of loaddisplacement curves.

\section{Materials}

Soil. The Hardening Soil model is an advanced model for modeling the behavior of multiple soil types, including soft and rigid soils [8]. The soil displays a decreasing stiffness when exposed to primary deviatoric loading, and permanent plastic strains grow at the same period. A hyperbola can approximate the observed relationship between the axial strain and the deviatoric stress in the special case of a drained triaxial measure. This relationship was initially established by [9] and utilized later in the renowned hyperbolic model [10]. However, the Hardening Soil model exceeds the hyperbolic model by far: first, using the principle of plasticity rather than elasticity, second, by using soil dilatancy, and third, by introducing a yield limit. The parameters of sand are listed in Table 1 . They are selected from the study conducted by [11]. All of the selected pile models have been modeled as solid sections (tetrahedral elements) and hollow sections (plate elements). The thickness of the hollow sections was kept as $1.44 \mathrm{~mm}$ as investigated by [11].

Table 1. Sand properties.

\begin{tabular}{|l|c|c|}
\hline \multicolumn{1}{|c|}{ Soil properties } & Unit & Value \\
\hline Dry unit weight, $\gamma$ & $\mathrm{kN} / \mathrm{m}^{3}$ & 15.5 \\
\hline Secant modulus, $\mathrm{E}_{50}$ & $\mathrm{kPa}$ & 15000 \\
\hline Odometer modulus, $\mathrm{E}_{\text {OED }}$ & $\mathrm{kPa}$ & 15000 \\
\hline Unloading/reloading modulus, $\mathrm{E}_{\mathrm{UR}}$ & $\mathrm{kPa}$ & 45000 \\
\hline Cohesion, $\mathrm{c}$ & $\mathrm{kPa}$ & 0.1 \\
\hline Friction angle, $\varphi$ & Degree & 31 \\
\hline Dilatancy angle, $\psi$ & Degree & 1 \\
\hline Poisson's ratio, $\nu$ & - & 0.2 \\
\hline Power for stiffness stress dependency, $\mathrm{m}$ & - & 0.625 \\
\hline $\mathrm{\gamma}_{0.7}$ & - & $0.176 \times 10^{-3}$ \\
\hline $\mathrm{G}_{0, \text { ref }}$ & $\mathrm{kPa}$ & 75000 \\
\hline
\end{tabular}


Steel Piles. The pile was modeled as a volume pile with three cross-sectional shapes (circular, square, and varied). The input properties of the piles are shown in Table 2:

Table 2 Parameters of volume piles

\begin{tabular}{|c|c|c|c|c|}
\hline Pile properties & Unit & Circular & Square & Tapered \\
\hline Unit weight, $\gamma$ & $\mathrm{kN} / \mathrm{m}^{3}$ & 78.5 & 78.5 & 78.5 \\
\hline $\mathrm{E}$ & $\mathrm{kPa}$ & $200 \mathrm{E} 6$ & $200 \mathrm{E} 6$ & $200 \mathrm{E} 6$ \\
\hline $\mathrm{R}_{\text {inter }}$ & - & 0.8 & 0.8 & 0.8 \\
\hline
\end{tabular}

Pile cap. The pile cap was modeled using plate element, which also consists of triangular surface elements with 6 nodes and 3 translational degrees of freedom per node (ux, uy and uz)[10]- [11]. As for the load, a vertical point load of 0.5 ton $(5 \mathrm{kN})$ was applied at the cap's center. The loading value was chosen based on trial and error to ensure that all piles would reach their capacity. Figure 2 shows a mesh view of the pile cap while Table 3 presents the cap's properties.

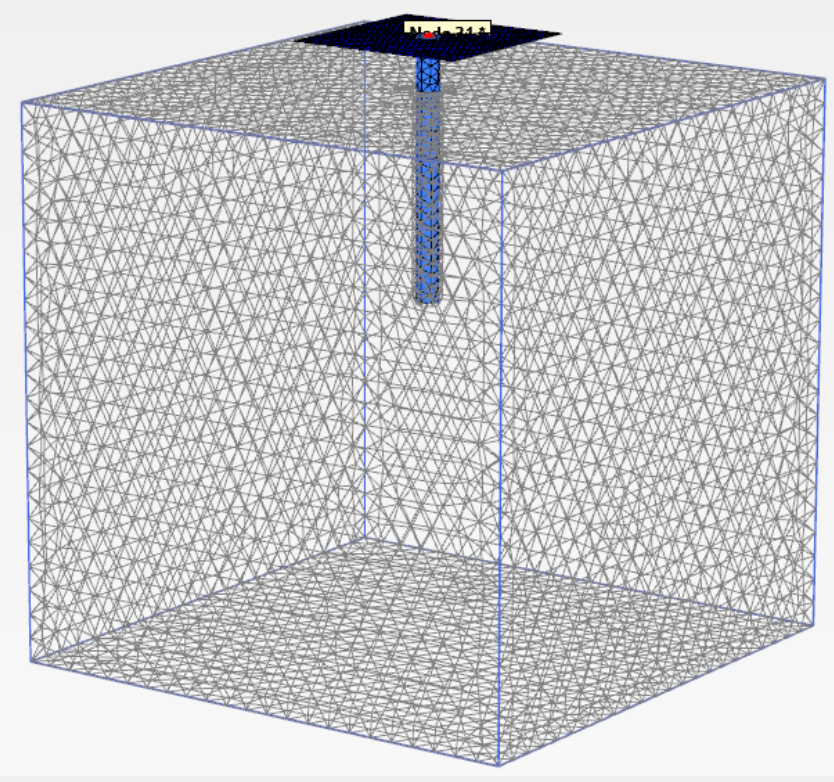

Figure 2. Pile cap model.

Table 3 Pile cap model.

\begin{tabular}{|c|c|c|}
\hline Pile section & D or B $(\mathbf{m m})$ & L/D or $\mathbf{L} / \mathbf{B}$ \\
\hline Circular & 30 & 15 \\
\hline Square & 30 & 15 \\
\hline Tapered (1.5b) & 45 & 15 \\
\hline Tapered (2b) & 60 & 15 \\
\hline Tapered (2.5b) & 75 & 15 \\
\hline Tapered (3b) & 90 & 15 \\
\hline
\end{tabular}

\section{Models}

The parametric study has been conducted to investigate the influence of multiple parameters on the axial capacity of steel piles in sandy soil, including the pile's cross-section, the section type (hollow and solid). The typical circular cross-section was selected as the reference section. Additionally, square and varied (tapered) sections were investigated in this study. The circular pile dimensions have been selected depending on the experimental study conducted by [11]. Table 4 summarizes the dimensions of the FE models, and Figure 3 shows the dimensions of the typical cross-sections, while Figure 4 shows the details of the tapered sections. 
[10]Duncan J. and Chang C .-Y., 1970. Nonlinear analysis of stress and strain in soils. J. Soil Mech. Found. Div., 9(5), 1629-1653.

[11]Fattah M. Y., Salim N. M., and Al-Gharrawi A., 2018. Incremental filling ratio of pipe pile groups in sandy soil," Geomech. Eng., 15(1), 695-710.

[12] Fattah M. Y., Hassan W. H., and Rasheed S. E., 2018. Numerical analysis of the effect of geocell reinforcement above buried pipes on surface settlement and vertical pressure. Int $\mathrm{J}$ Geotechn Geol Eng, 12(3), 221-227.

[13]Fattah M. Y., Hassan W. H., and Rasheed S. E., 2018. Behavior of flexible buried pipes under geocell reinforced subbase subjected to repeated loading. Int. J. Geotech. Earthq. Eng., 9(1), 22 41.

[14] Prakash S. and Ghumman M. S., 1978. Effect of shape on bearing capacity of model footings in sand. J. Inst. Eng. Civ. Eng. Div., 59(4), 185-191. 
Table 4. Dimensions of the FE models.

\begin{tabular}{|l|c|c|}
\hline \multicolumn{1}{|c|}{ Pile cap model } & Properties & Unit \\
\hline Unit weight, $\gamma$ & 78.5 & $\mathrm{kN} / \mathrm{m}^{3}$ \\
\hline E & $200 \times 10^{6}$ & $\mathrm{kPa}$ \\
\hline Poisson's ratio & 0.2 & - \\
\hline Thickness & 5 & $\mathrm{~mm}$ \\
\hline
\end{tabular}

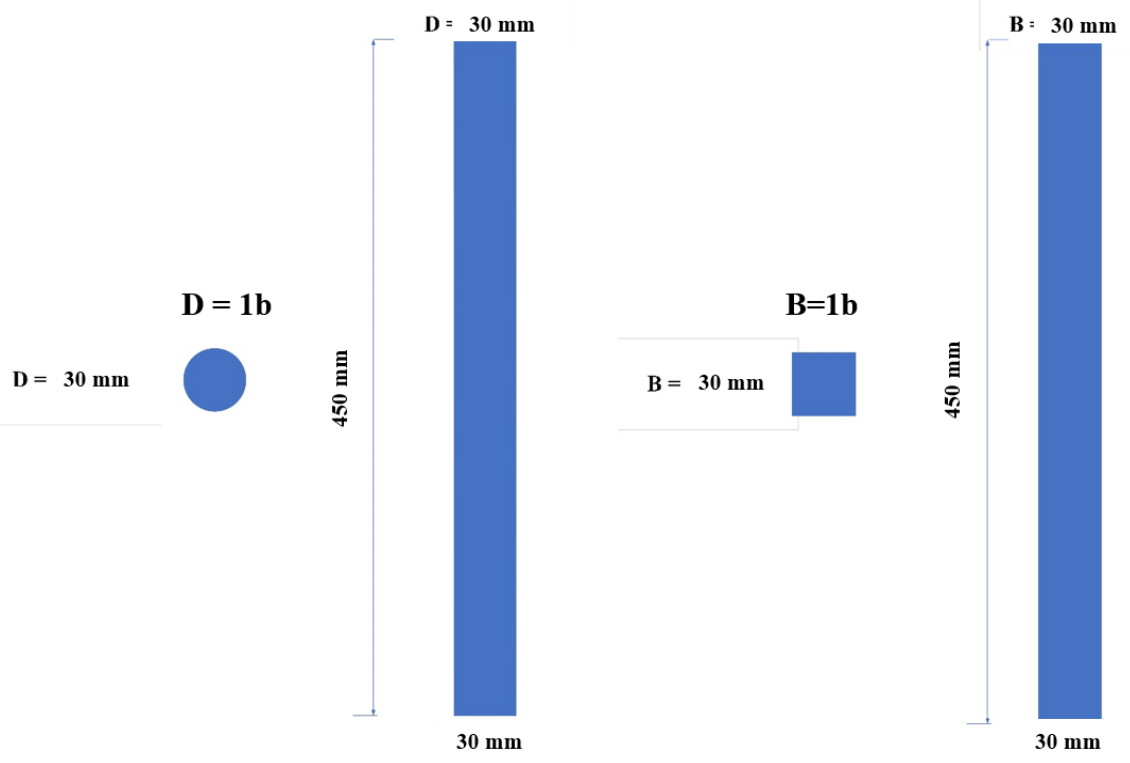

Figure 3. Dimensions of the typical pile sections: a) circular section. b) square section.

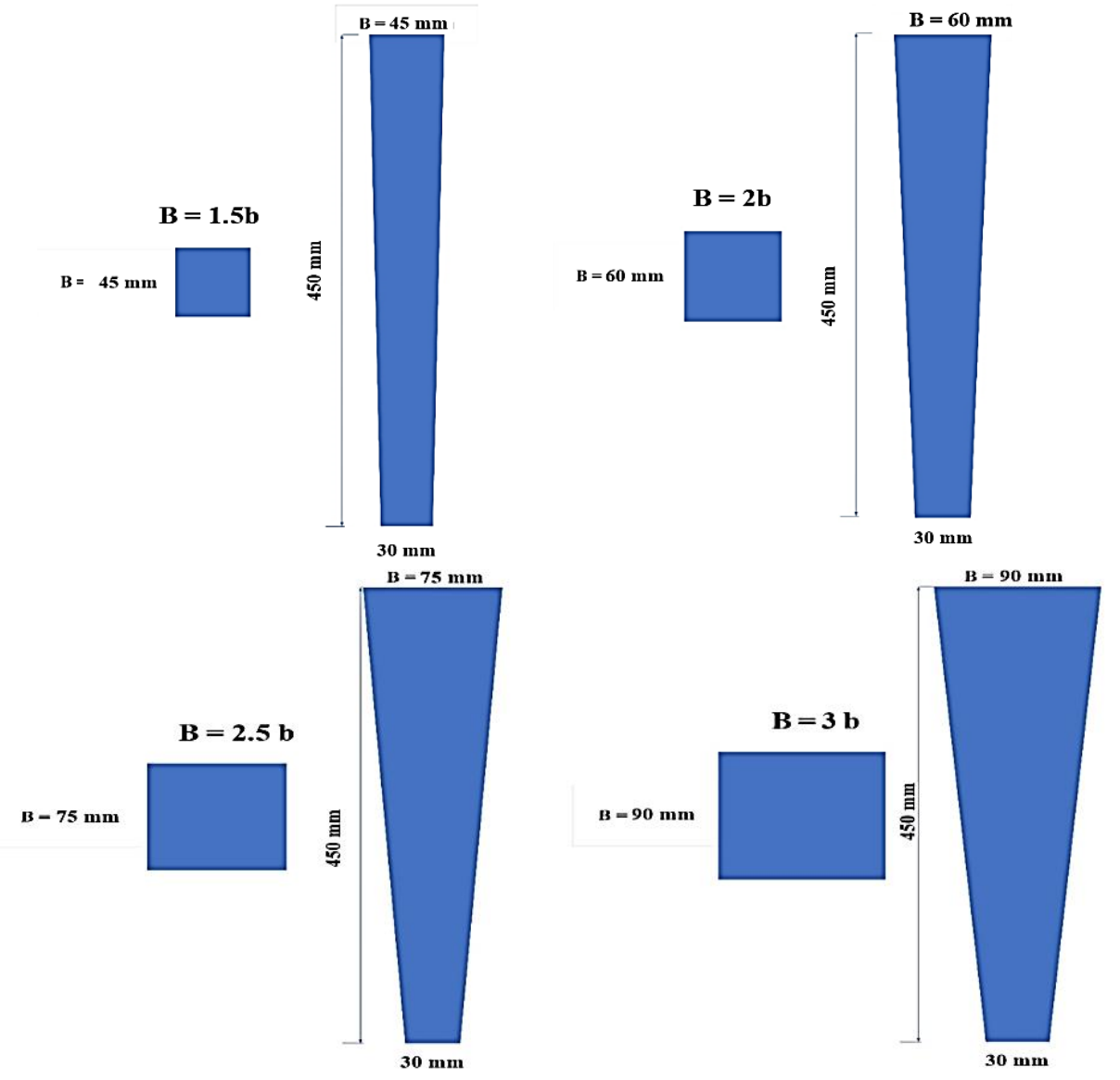

Figure 4. Dimensions of the tapered cross-sections. 


\section{Results and Discussion}

Figure 5 present the results of the load-displacement curve for the solid and hollow circular and square pile. For the circular section, the solid section's axial loading capacity was $1622 \mathrm{~N}$ and $837 \mathrm{~N}$ for the hollow section. The solid circular section's ultimate load capacity was higher than the experimental results obtained by [11], which was $565 \mathrm{~N}$ while the open-ended section exhibited a closer value of load capacity $(685 \mathrm{~N})$. The difference in these values can be attributed to the rate of loading and different testing conditions. The square solid and hollow section's axial loading capacity was $2132 \mathrm{~N}$ and $1562 \mathrm{~N}$, respectively, which were significantly higher than those of the circular section. These values shall be used as reference values to compare all the models analyzed in this study. The hollow circular and square sections showed the lowest axial load capacity compared to the solid circular and square because of the largest end bearing component in sandy soil.

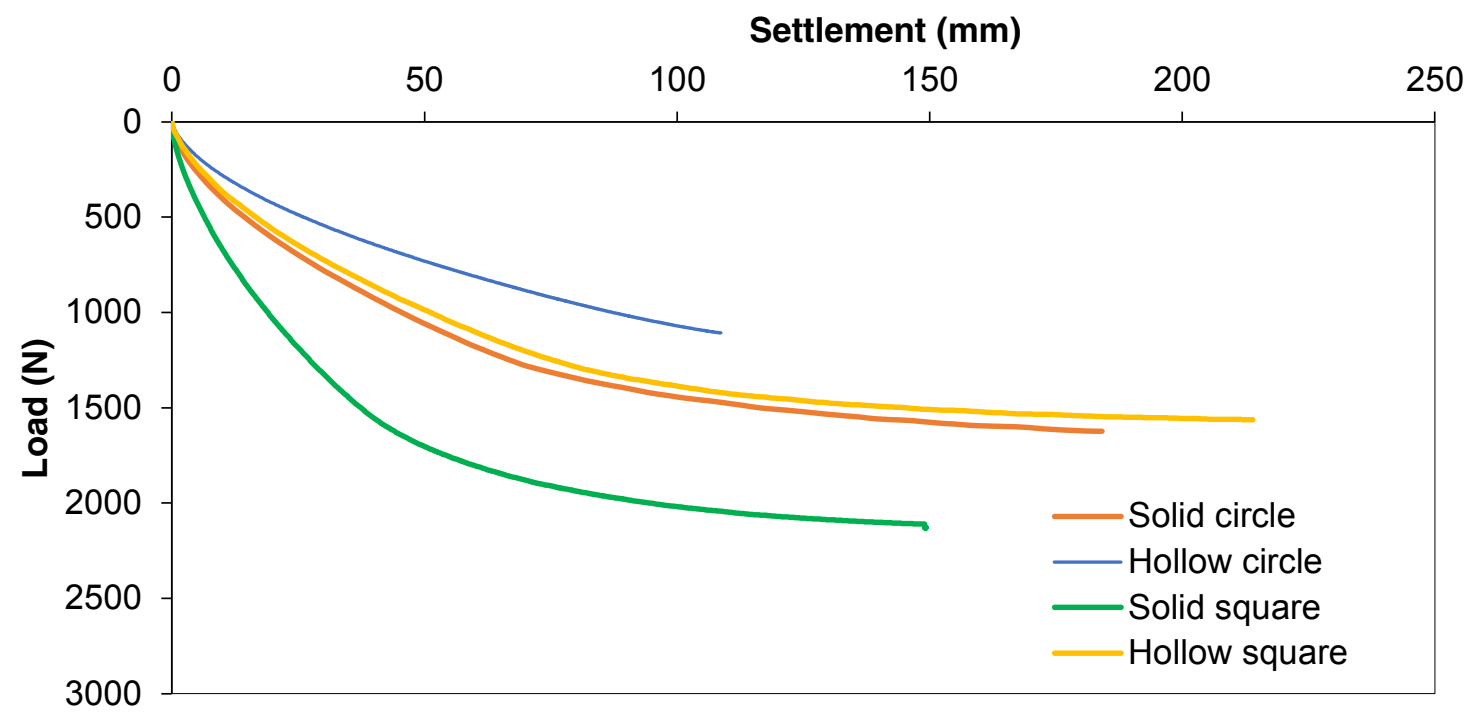

Figure 5. Load-displacement curve for the circular and square sections.

Effect of Pile Shape. Figure 6 summarizes the results for the close-ended (solid) sections, and Figure 7 summarizes the results of the open-ended (hollow) sections. Figures 6 and 7 show the results of the tapered solid and hollow sections. It can be shown that the maximum axial load capacity of the tapered pile (3b) was $2868 \mathrm{~N}$ and $2387 \mathrm{~N}$ for the solid section and the hollow section, respectively. The remaining tapered models showed a decrease in the values of load capacity with decreasing the section size. The tapered section (2.5b) produced slightly lower values for a load capacity of $2650 \mathrm{~N}$ for the solid section and $2181 \mathrm{~N}$ for the hollow section. The $(2 \mathrm{~b})$ section capacities were $2473 \mathrm{~N}$ and $1924 \mathrm{~N}$ for the solid and the hollow sections, respectively. The (1.5b) section showed the lowest loadcapacity values for both sections, with $2324 \mathrm{~N}$ for the solid section and $1768 \mathrm{~N}$ for the hollow section. These results show that increasing the tapering area increases the axial load capacity for both the solid and the hollow sections. The results also demonstrated that the tapering pile is much more efficient than any straight-sided pile or even circular pile [14]. In terms of the displacement values, all of the tapered piles showed relatively similar values ranging from $113 \mathrm{~mm}$ for the $(1.5 \mathrm{~b})$ section to $130 \mathrm{~mm}$ for the $(2.5 \mathrm{~b})$ section for the close-ended (solid) sections. For the open-sided (hollow) sections, the displacement values also were relatively close, ranging from $102 \mathrm{~mm}$ for the (2b) section to $113 \mathrm{~mm}$ for the (1.5b) section. It should be noted that the displacement increases proportionally with axial pile capacity due to the failure of soil occurring at later loading stages; hence the pile is displaced further. However, it should be mentioned that there was no significant difference in the values of pile displacement due to the loose state of the utilized soil. 


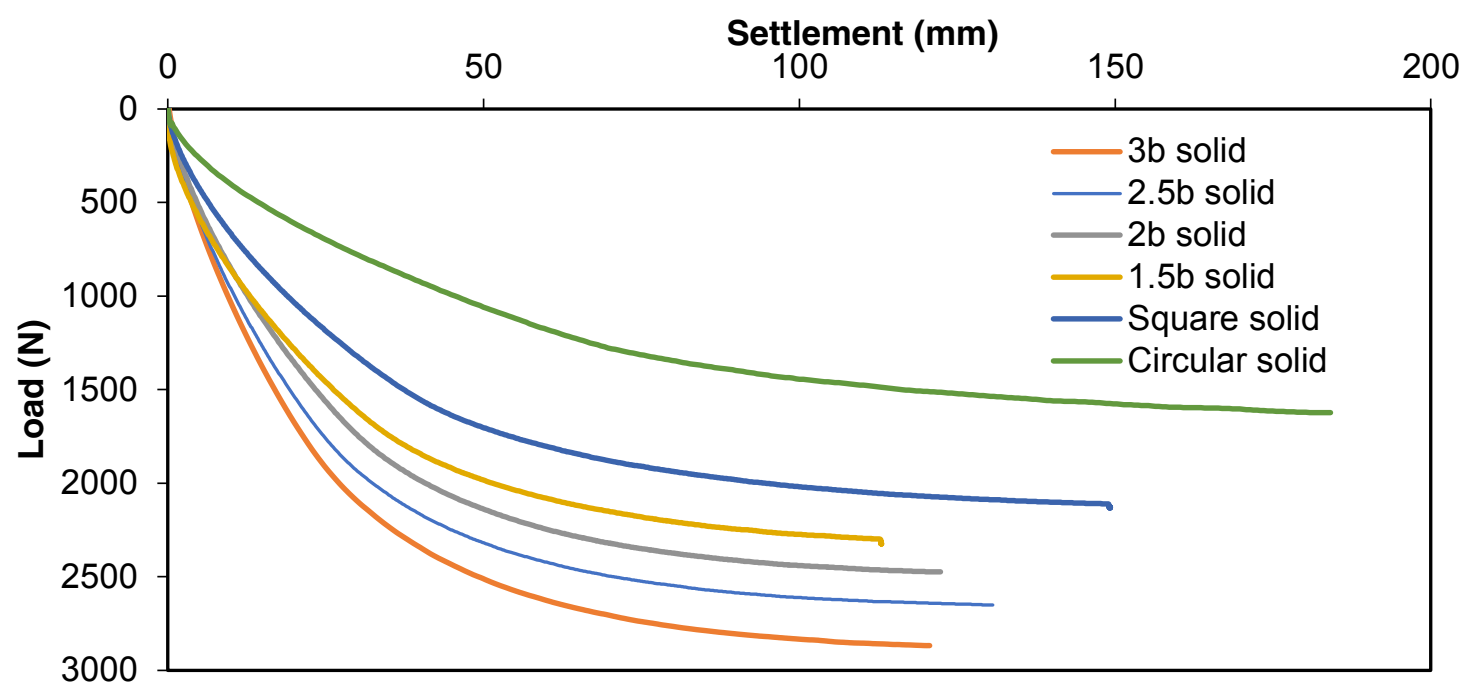

Figure 6. Load-displacement curve for all the solid sections.

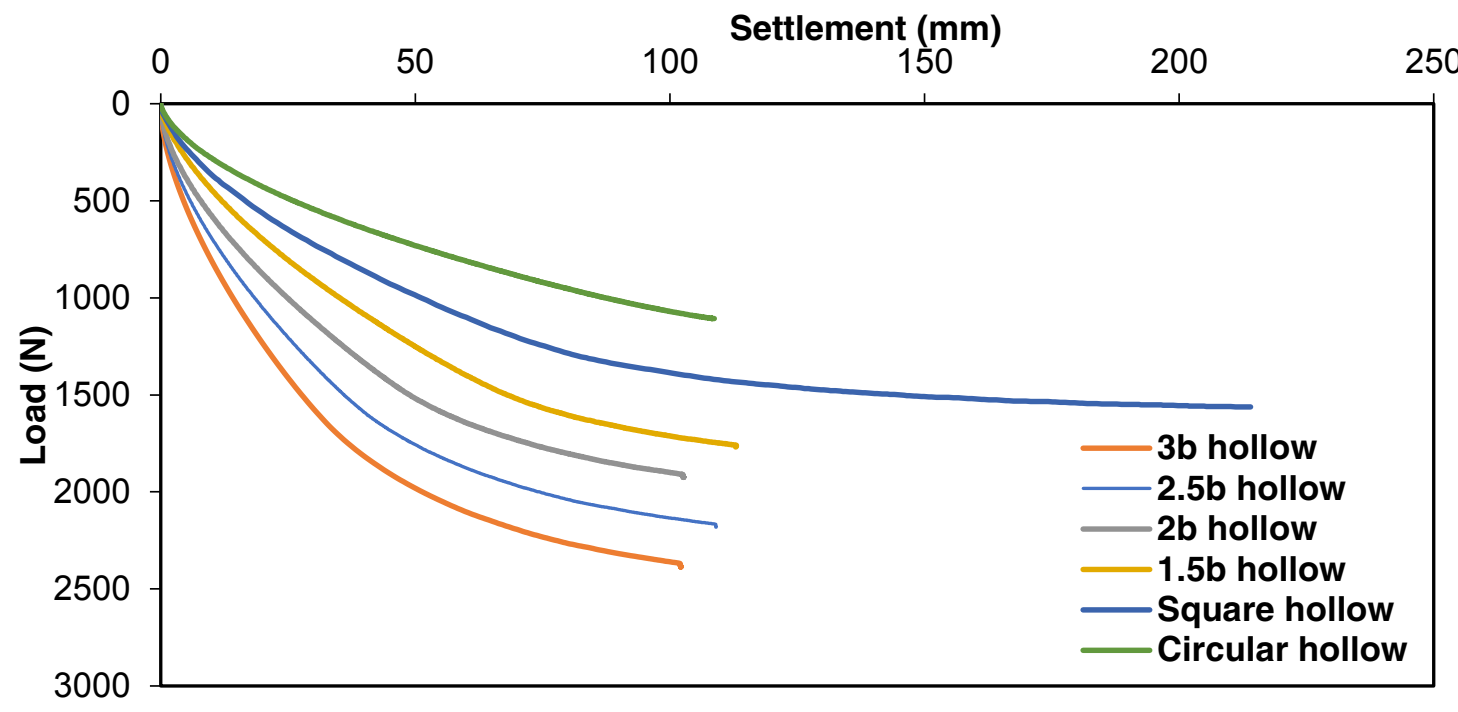

Figure 7. Load-displacement curve for all the hollow sections.

Table 5 presents a summary of the axial load capacity results, while Table 6 summarizes the results for displacement.

Table 5. A summary of the results of the axial load capacity.

\begin{tabular}{|c|c|c|c|c|c|c|c|}
\hline \multicolumn{2}{|c|}{ Shape } & Circular & Square & $\begin{array}{c}\text { Tapered } \\
\mathbf{1 . 5 b}\end{array}$ & $\begin{array}{c}\text { Tapered } \\
\mathbf{2 b}\end{array}$ & $\begin{array}{c}\text { Tapered } \\
\mathbf{2 . 5 b}\end{array}$ & $\begin{array}{c}\text { Tapered } \\
\mathbf{3 b}\end{array}$ \\
\hline \multicolumn{2}{|c|}{ Solid } & $1623 \mathrm{~N}$ & $2132 \mathrm{~N}$ & $2323 \mathrm{~N}$ & $2473 \mathrm{~N}$ & $2650 \mathrm{~N}$ & $2868 \mathrm{~N}$ \\
\hline \multicolumn{2}{c|}{ Hollow } & $1107 \mathrm{~N}$ & $1562 \mathrm{~N}$ & $1759 \mathrm{~N}$ & $1924 \mathrm{~N}$ & $2181 \mathrm{~N}$ & $2387 \mathrm{~N}$ \\
\hline $\begin{array}{c}\text { Ratio of load- } \\
\text { capacity to solid } \\
\text { circular section }\end{array}$ & Solid & $100 \%$ & $131 \%$ & $143 \%$ & $152 \%$ & $163 \%$ & $176 \%$ \\
\cline { 2 - 8 } & Hollow & $68 \%$ & $96 \%$ & $108 \%$ & $118 \%$ & $134 \%$ & $147 \%$ \\
\hline $\begin{array}{c}\text { Ratio of load- } \\
\text { capacity to solid } \\
\text { square section }\end{array}$ & Solid & $76 \%$ & $100 \%$ & $82 \%$ & $90 \%$ & $102 \%$ & $134 \%$ \\
\cline { 2 - 8 } & Hollow & $51 \%$ & $73 \%$ & $108 \%$ & $118 \%$ & $134 \%$ & $111 \%$ \\
\hline
\end{tabular}


Table 6. A summary of the displacement results.

\begin{tabular}{|c|c|c|c|c|c|c|c|}
\hline \multicolumn{2}{|c|}{ Shape } & Circular & Square & $\begin{array}{c}\text { Tapered } \\
\mathbf{1 . 5 b}\end{array}$ & $\begin{array}{c}\text { Tapered } \\
\mathbf{2 b}\end{array}$ & $\begin{array}{c}\text { Tapered } \\
\mathbf{2 . 5 b}\end{array}$ & $\begin{array}{c}\text { Tapered } \\
\mathbf{3 b}\end{array}$ \\
\hline \multicolumn{2}{|c|}{ Solid } & $184 \mathrm{~mm}$ & $149 \mathrm{~mm}$ & $113 \mathrm{~mm}$ & $122 \mathrm{~mm}$ & $130 \mathrm{~mm}$ & $120 \mathrm{~mm}$ \\
\hline \multicolumn{2}{|c|}{ Hollow } & $108 \mathrm{~mm}$ & $213 \mathrm{~mm}$ & $113 \mathrm{~mm}$ & $102 \mathrm{~mm}$ & $109 \mathrm{~mm}$ & $102 \mathrm{~mm}$ \\
\hline $\begin{array}{c}\text { Ratio of } \\
\text { displacement to } \\
\text { solid circular } \\
\text { section }\end{array}$ & Solid & $100 \%$ & $81 \%$ & $61 \%$ & $66 \%$ & $71 \%$ & $65 \%$ \\
\cline { 2 - 8 } & Hollow & $59 \%$ & $116 \%$ & $61 \%$ & $55 \%$ & $59 \%$ & $55 \%$ \\
\hline $\begin{array}{c}\text { Ratio of } \\
\text { displacement to } \\
\text { solid square } \\
\text { section }\end{array}$ & Solid & $123 \%$ & $100 \%$ & $76 \%$ & $82 \%$ & $87 \%$ & $81 \%$ \\
\cline { 2 - 8 } & Hollow & $72 \%$ & $143 \%$ & $76 \%$ & $68 \%$ & $73 \%$ & $68 \%$ \\
\hline
\end{tabular}

Displacement Contours. In this section, graphical representations of the total displacement in the cross-sections will be displayed in Figures 8 to 13 show the state of the FE models at the moment of soil failure.

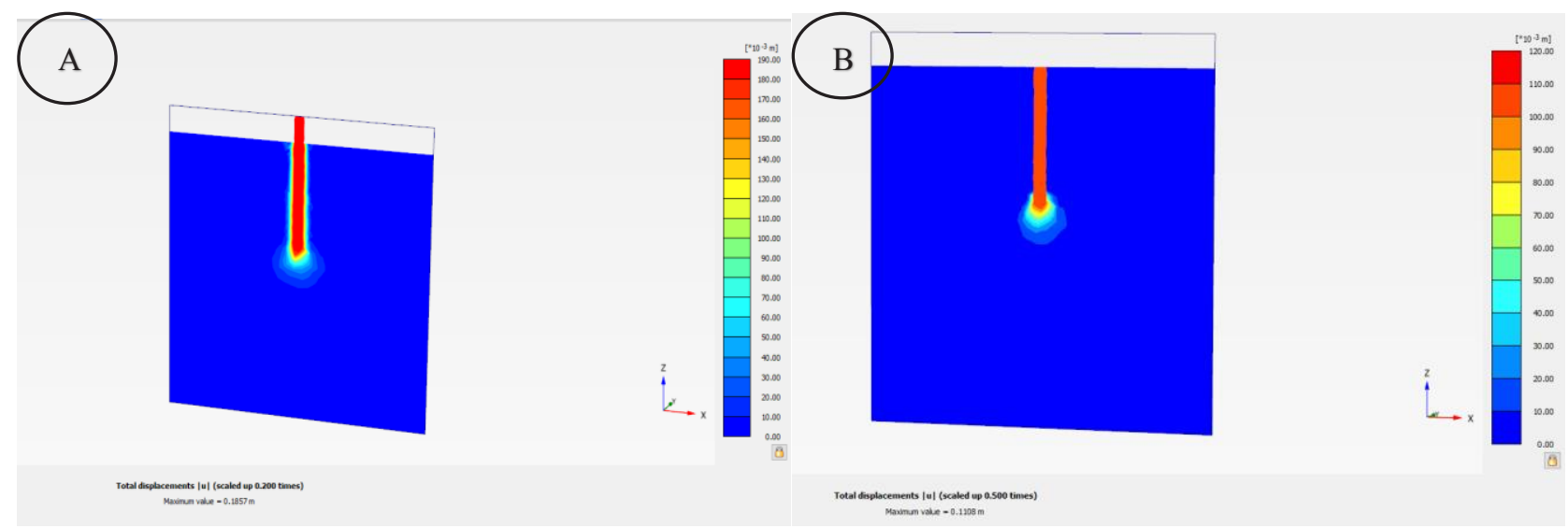

Figure 8. Total displacement for the circular sections, A. Solid section, and B. Hollow section.

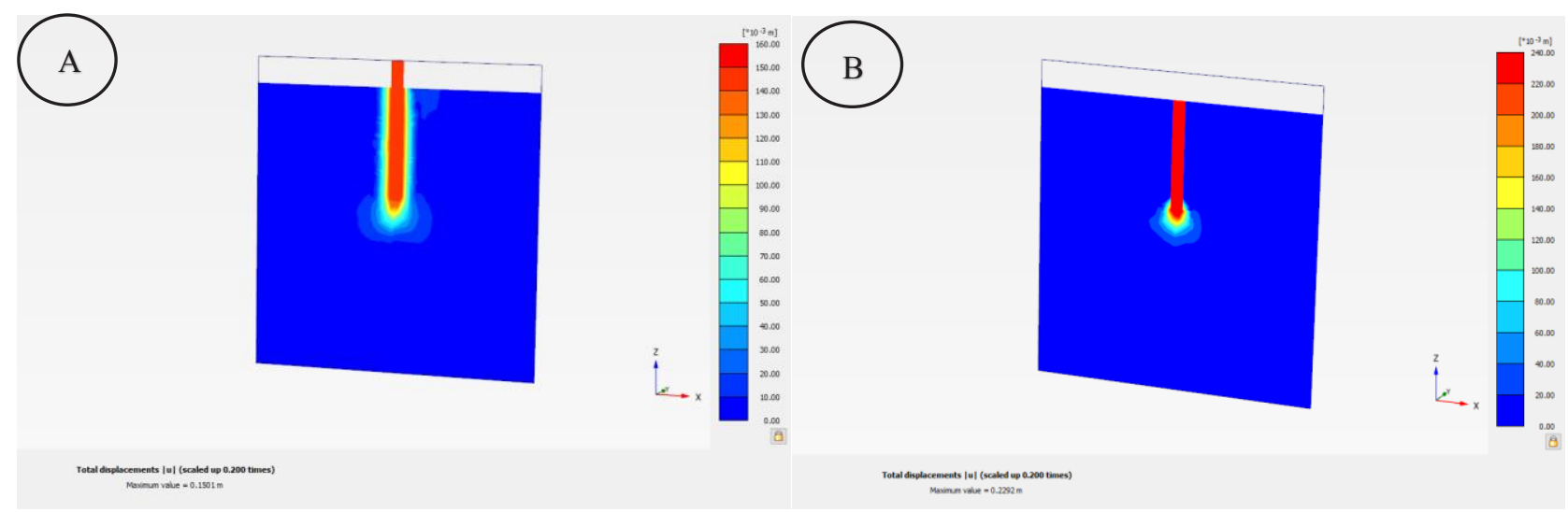

Figure 9. Total displacement for the square sections, A. Solid section, and B. Hollow section. 


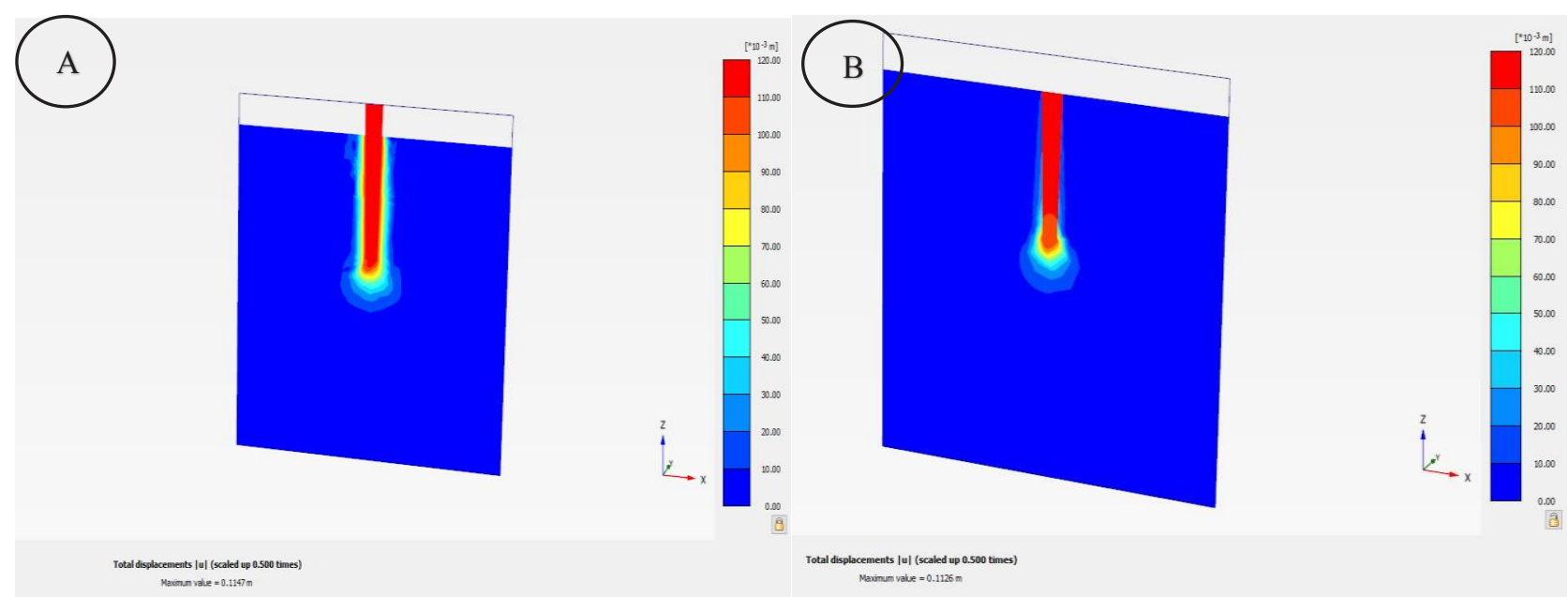

Figure 10. Total displacement for the tapered $1.5 \mathrm{~b}$ sections, A. Solid section, and B. Hollow section.

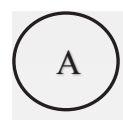

A
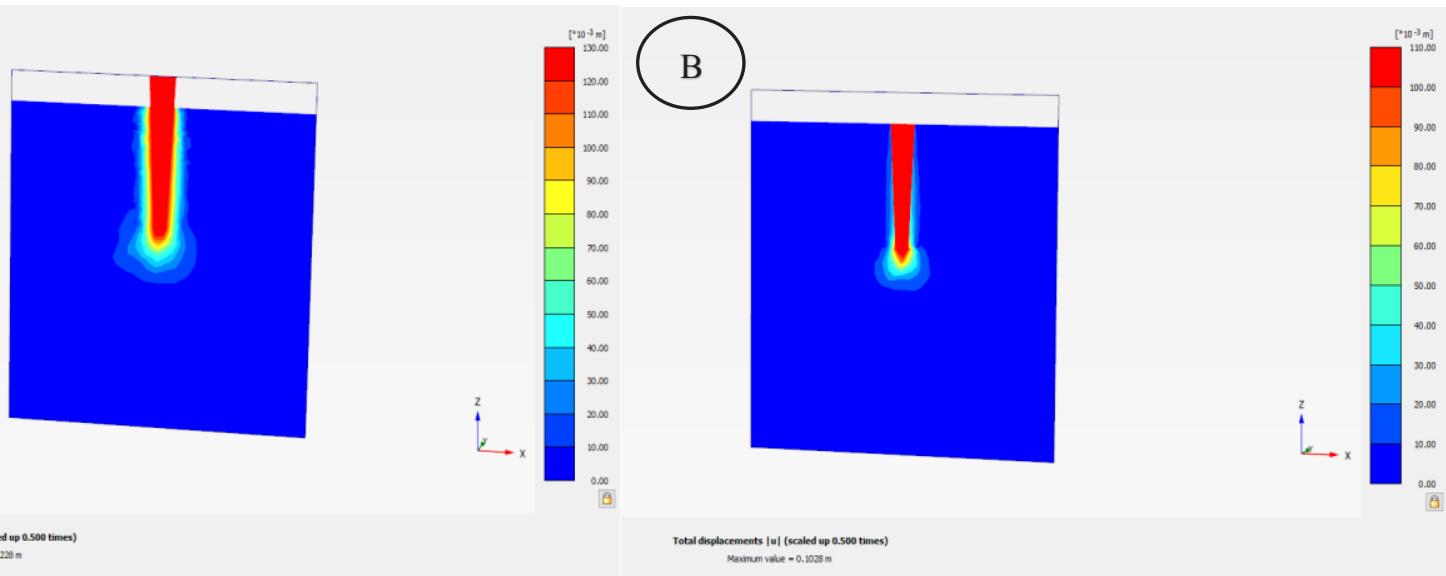

tainn iste $=0.128 \mathrm{~m}=$

Figure 11. Total displacement for the tapered $2 \mathrm{~b}$ sections, A. Solid section and B. Hollow section.
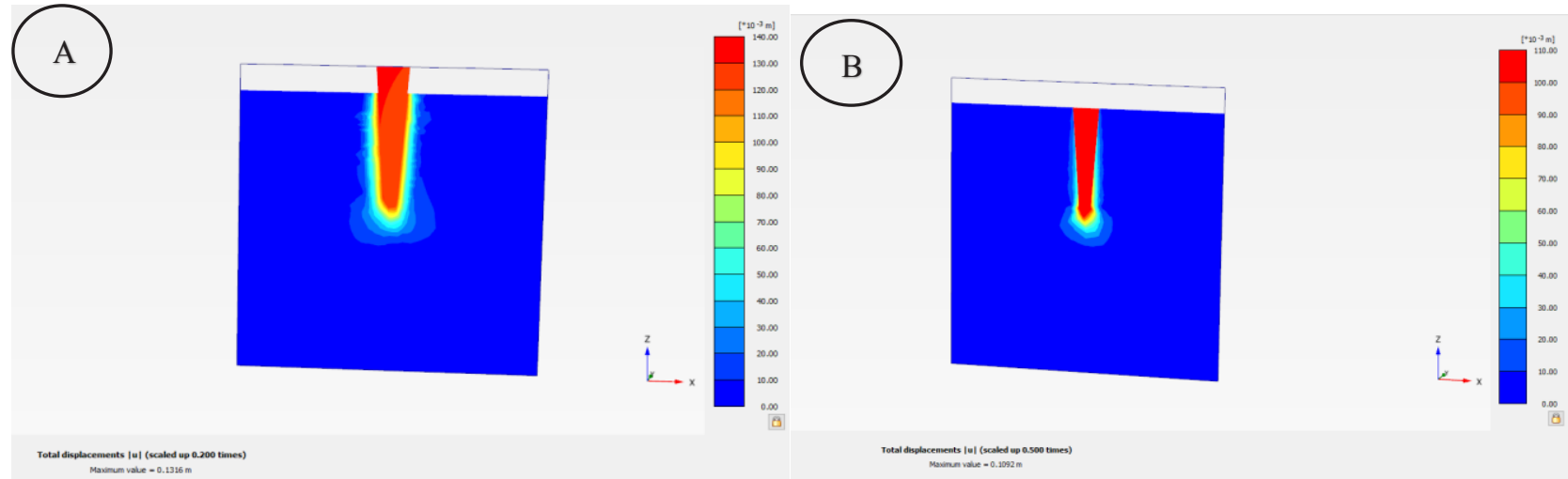

Figure 12. Total displacement for the tapered $2.5 \mathrm{~b}$ sections, A. Solid section, and B. Hollow section. 


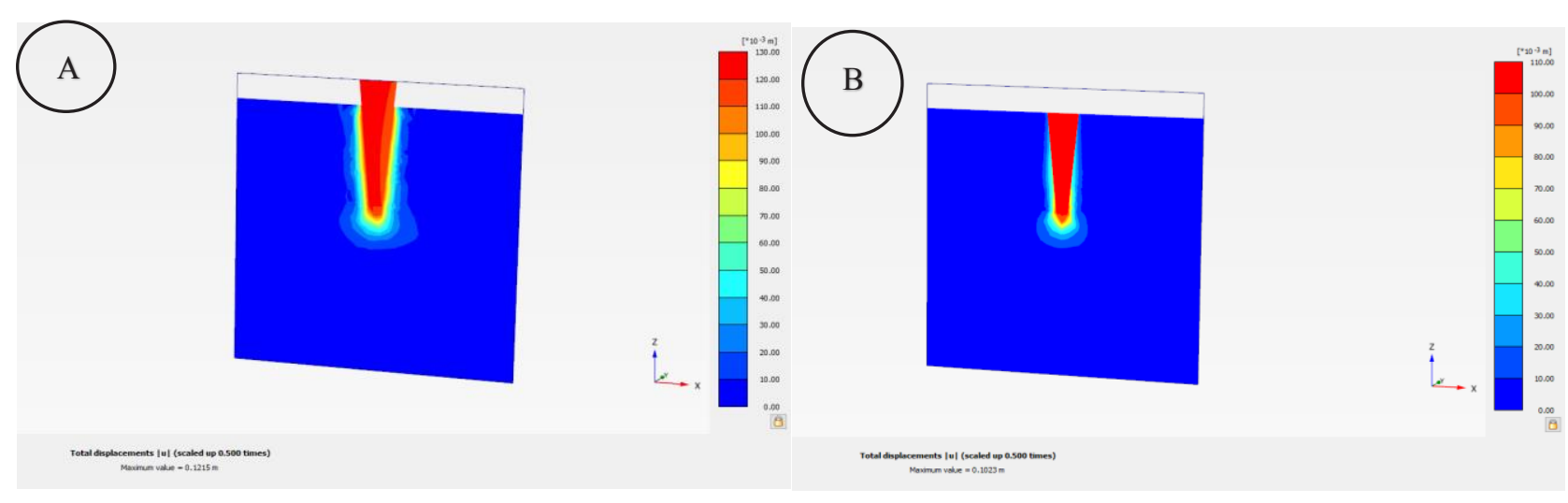

Figure 13. Total displacement for the tapered $3 \mathrm{~b}$ sections, A. Solid section and B. Hollow section.

\section{Conclusions}

This study deals with the effect of pile type, pile shape on the axial loading capacity. Two FE models (solid and hollow) have been conducted in this study using the FE package PLAXIS 3D V20. The following can be concluded from the results:

- The open-ended (hollow) circular model has demonstrated the lowest values of load capacity of $1107 \mathrm{~N}$.

- The close-ended (solid) tapered section (3b) showed the highest load capacity of $2868 \mathrm{~N}$ with an increment ratio of $176 \%$ and $134 \%$ compared to the solid circular and solid square sections.

- Increasing the upper cross-sectional area of the tapering section increases the load capacity.

- The load capacities of close-ended (solid) piles were higher than the open-ended (hollow) pipes for all the utilized sections.

- The close-ended (solid) circular section showed the highest pile displacement of $184 \mathrm{~mm}$.

- Both of the open-ended (hollow) tapered sections $2 \mathrm{~b}$ and $3 \mathrm{~b}$ have resulted in the lowest pile displacement values with only $102 \mathrm{~mm}$ for both sections.

- There was no significant difference in terms of pile displacement in all of the models due to the soil's loose state.

\section{References}

[1] Polhem C., 2008. Pile foundation design : A student guide introduction to pile foundations.

[2] Grand B. A., 1970. Types of piles: Their characteristics and general use the purpose of a pile foundation. Comm. Substruct. Retaining Walls Found. Present. 49th Annu. Meet., no. c, 3-15.

[3] Robinsky E. I., Sagar W. L., and Morrison C. F., 1964. Effect of shape and volume on the capacity of model piles in sand. Can. Geotech. J., 1(4), 189-204.

[4] Ladanyi B. and Guichaoua A., 1985. Bearing capacity and settlement of shaped piles in permafrost. Proceedings of the eleventh international conference on soil mechanics and foundation engineering, San Francisco.

[5] Rybnikov A. M., 1990. Experimental investigations of bearing capacity of bored-cast-in-place tapered piles. Soil Mech. Found. Eng., 27(2), 48-52.

[6] Rahil F. H., Al-Neami M. A., and Al-Zaho K. A. N., 2016. Effect of relative density on behavior of single pile and piles groups embedded with different lengths in sand. Eng. Technol. J., 34(6) Part (A) Engineering.

[7] Al-Neami M. and Wasmi M., 2018. Influence of cyclic loading on performance of steel piles in sandy soil. in MATEC Web of Conferences, 162, 1012.

[8] Schanz T., 1998. Zur modellierung des mechanischen verhaltens von reibungsmaterialen," Mitteilungen des Instituts für Geotech. der Univ. Stuttgart, H. 45.

[9] Kondner R. L. and Z. J. S., 1963. A hyperbolic stress-strain formulation for sands. in In 2nd Pan. Am. Conf. Soil Mech. Found. Eng., 289-394. 
[10] Duncan J. and Chang C .-Y., 1970. Nonlinear analysis of stress and strain in soils. J. Soil Mech. Found. Div., 9(5), 1629-1653.

[11]Fattah M. Y., Salim N. M., and Al-Gharrawi A., 2018. Incremental filling ratio of pipe pile groups in sandy soil," Geomech. Eng., 15(1), 695-710.

[12] Fattah M. Y., Hassan W. H., and Rasheed S. E., 2018. Numerical analysis of the effect of geocell reinforcement above buried pipes on surface settlement and vertical pressure. Int J Geotechn Geol Eng, 12(3), 221-227.

[13]Fattah M. Y., Hassan W. H., and Rasheed S. E., 2018. Behavior of flexible buried pipes under geocell reinforced subbase subjected to repeated loading. Int. J. Geotech. Earthq. Eng., 9(1), 22 41.

[14] Prakash S. and Ghumman M. S., 1978. Effect of shape on bearing capacity of model footings in sand. J. Inst. Eng. Civ. Eng. Div., 59(4), 185-191. 